\title{
Applied Analysis of Social Criticism Theory on the Base of Russian Literary Works
}

\author{
Leyla Hacizade \\ Selçuk University, Konya, Turkey
}

\begin{abstract}
Lermontov, who lived and gave masterpieces in 19th century known as golden age of Russian literature, had thought on conflict of good and bad throughout his life and reflected it to his works. In the most part of his works, there are struggles of good with bad. This analysis should be done in concept of social determinism, so it must be done in the light of social criticism theory. In his work "Beyond Good and Evil" Nietzche asked some questions like "What is good? What is bad?", too. In our study we'll try to analyze the famous philosopher's opinions in Lermontov's "Masquerade" by reviewing these opinions in the concept of social criticism. This study has an interesting point of view like analyzing the place of a Russian writer in the parallel of Europian literature.
\end{abstract}

Keywords: Good, Bad, Conflict, Social Determinism, Concept

\section{Introduction}

19th century is a golden age of Russian literature, for the reason that in this age many well-known writers and critics lived and gave masterpieces. Some of these famous writers and critics are: Karamzin, Zhukovksy, Krylov, Griboyedov, Pushkin, Gogol, Lermontov, Turgenev, Nekrasov, Dostoevsky, Tolstoy, Chekhov, Chernyshevsky, Belinsky, Dobroliubov, etc. Like the other fields related with human, literature has also evolved in line with supply and demand. If there weren't any fruitful fields, there couldn't grow well any plant. This metaphor is also applies to literature. Because, 19th century is Russia's very complicated period: there were social events like discussions about the law serfdom, wars, etc. These complex events were the basic themes and material to the literature.

Mikhail Lermontov, who is the writer of our research object work, lived in this age and gave masterpieces, too. In these masterpieces it can be seen writer's thoughts about contrast of good and bad ("Demon", "A Hero of Our Time", "Masquerade"). He reflected his philosophical opinions on his works. In the most part of his works, there are struggles of good with bad. The writer was a witness of Russia's complicated period; so the reason of his thoughts might be social events, a place of man in society and questions like what should humanistic values be. That's why, we chose social criticism for analyze method.

A concept of social criticism is chosen for analyzing and tried to do it in the light of social criticism theory. "Sociological criticism, follows the principle that literature doesn't exist on its own, it was born in the community

Leyla Hacizade, Department of Russian Language and Literature, Selçuk University, Konya, Turkey. leylahacizade@yahoo.com 
and it is an expression of that society. Whereas the social conditions determine the author, his work and reader, then work to be done, is to act like a scientist and explain art-related problems giving some thoughts to these conditions" (Moran, 2004, p. 83). The beginning of this criticism, according to some critics, is Vico's "La Scienza Nuova" (1725), though, Hippolyte Taine was the first who used it literally.

Indeed, the social criticism theory, as an idea, was started with Plato's mimesis (mirroring) understanding. According to him, literature is not very necessary, but if it should be exist, then it shouldd be beneficial for society. The famous philosopher, by defining the ideal state, icludes also a literature in his definition. He sees literature, as a tool of çivil service. Plato, who sees the literature as a mirror of the society, says that bad images in literary works may corrupt society, but good ones will improve it. In this definition literature is infront of the mirror, but society, standing in the mirror, imitates the literature. So, all kinds of good or bad characters and behaviors in literary works will be emulated and adopted by the society, in time they will be accepted as normal. Social criticism founded by Plato's was then developed by Tolstoy. Tolstoy, has gained a new dimensions to this view, by adding his moral philosophy. The famous Russian writer, that construes social criticism through religious framework, approaches with not the meaning of one person / community, but with the meaning of humanity, when he makes his critical evaluations. After Tolstoy there has been many famous philosophers and theorists contributing significantly to this critical theory. One of the best known of these is Marx, and the other is Nietzsche. Marx has founded the Marxism, adding political nuances to social criticism. Rather, he put forward the idea of a new social order with infrastructure-superstructure formula based on Plato's ideal state thought; and has had a support of Engels about this. Later, this Marxist theory was adapted to language by Plekhanov's ideas. Nevertheless, it was Lenin, who gained political identity to this idea and put it into practice as a state order. However, these opinions also have differences among themselves. Namely, “Tolstoy's feelings as sympathy and confidence to poor, lower class aren't seen in Plato. Tolstoy didn't agree with Plato's request to ban the works of art. ... Tolstoy's pacifist religious understanding is not suitable at all for Marxist class struggle” (Moran, 2004, p. 126). In her work of "Literary Theory", Aytaç addressed an issue of relationship between morality and aesthetics; besides, she reinforced this issue, that she analyzed through the literary history, with the views of the authors and critics about relationships of morality and aesthetics in Western literature (Aytac, 2009, pp. 212-215).

The most characteristic property that distinguished Nietzsche from the other social critic, is that, rather than a community, he saw and evaluated every person as an individual.

Now we want to explain Nietzsche's philosophical work of "Beyond good and evil". In his work, Nietzsche displayed the contradictory aspects of Europe's main values. His work presented that the religion has contrasts. His philosophical criticism supported to destroy metaphysical concepts by explaining virtue's wicked aspect, and that the good is morally basic on the bad.

For Nietzsche metaphysical concepts of the reality are determined with his conflicts and opposites inside.

In his work of "Beyond Good and Evil", Nietzsche evaluated social criticism from a philosopher view an also showed his ideas about morality. The author gave a detailed description of Master and Slave morality. He described the "Overman" (Übermensch) in this philosophical work. In this study there were questioned good and evil by a philosophical point of view. That is the common thread to all this, between Lermontov and Nietzsche. Both have presented various opinions on good and evil, and have contributed to social criticism theory by comparing their views with social values. In our study we tried to analyze the famous philosopher's opinions in 
Lermontov's "Masquerade" by reviewing these opinions in the concept of social criticism.

What is good? What is bad? Do these two concepts struggle with each other? What are the places of good and bad in social thought? It was tried to find the answers to all these questions with the Nietzsche's philosophic views and Lermontov's way of showing it in his drama.

Before we pass on to our main obcejct, social analyze of "Masquerade", we want to shortly introduce Lermontov. Mikhail Yuryevich Lermontov (1814-1841) is a Russian Romantic writer, poet and also a painter, the most important Russian poet after Alexander Pushkin. He is the greatest figure in Russian Romaticism and gave the first sample of social-pchycologic novel in Russian literature, named "A hero of our time". Some of his works are: "The Corsair", "Oleg", "Two brothers", "The reed", "Mermaid", "The wish", "The angel", "Vadim", "Ismail-Bey", "Princess Ligovskaya", "Death of the poet", "Demon", "The Novice (Mtsyry)", "A hehro of our times" and of course "Masquerade".

The themes of writer's works are mainly: (1) Motherland and freedom (in these works we can also see the hate of writer to pressure on people and to feudalism; (2) Phylosophical ideas and minds (in these works Lermontov gave an importance to human mind and wisdom.); (3) In 30ies he gave historical works; (4) In some works author determined the spiritual emptiness of Russian high society in 19th century; (5) Loneliness and pessimism; (6) In some works (Demon) we can see inner hesitations of rebel soul and that he was ready to be purified from all badness and to make peace with Godness. In these works we can also see objection of World-order and social relationships; (7) In other works (A hero of our time) it's seen Hero's objection to society.

Then what kind of the Lermontov's work Masquerade is? It's a drama and was written in 1835; it got re-worked several times and the author tried desperately to publish it. Close to French melodrama and influenced by Victor Hugo and Alexander Dumas (but also owing a lot to Shakespeare, Griboyedov and Pushkin), Masquerade featured another hero that was in opposition to unsympathetic society and then get tired of his own conflicting nature. However, he was interesting mostly for its realistic sketches of the high society life, which Lermontov criticized more and more.

The hero Yevgeniy Arbenin is one of the rich and noble. This hero who had any kind of experiences in his youth, after he got married, he set aside all of that experiences, like the flirtatiousness and gambling. His wife Nina Arbenina, loves him and she is young and noble.

The drama begins with a game played at the gambling table at the invitation of one of the nobles. Here Arbenin, helped to Prince Zvyozdich who is about to lose the game and thus he won the game.

Later events happen in a masquerade. At this masquerade one masked woman (Baroness Stral) approached to the Prince and declares her love for him. Prince asked her to give him something like a souvenir to remember. Baroness gave him a bracelet, found by her before on the floor, during the masquerade. Bracelet belongs to Arbenin's wife Nina, neither Baroness, nor Prince do not know it. Prince, approached to Arbenin and told him that he found the love of his life, showing bracelet.

Other scene comes about in Arbenin's house. When Arbenin came home, he realized that his wife hadn't return home, yet. After returning of his wife to home, he saw that her bracelet was disappeared. Arbenin doesn't believe in his wife's fidelity any more. Elapsed some time. Meanwhile, there were spread rumors about Nina and Zvyozdich in high society. Prince found who Nina is actually, but he had no news about the fact that she's Evgeny's wife. Without knowing that, he wrote to Nina a letter. Arbenin got this letter and went to Prince's house 
to talk to him, there he saw the Baroness. Understanding that she made a mistake, Baroness told the situation to Prince. She told him that the masked woman who declared her love for him at masquerade was her. Unfortunately it is too late for everything. The last stage of the work occurs at one of high society invitations. During this invitation it has been gambling again on the game table. Yevgeniy Arbenin invited Prince Zvyozdich to table to play with him. During the games Arbenin left the table telling that the Prince sharped. Thus the Prince has lost his all honor and dignity in society. Thinking that he paid the Prince back Arbenin, killed his wife by poisoning. After the death of his wife, the Prince gave him Baroness's letter, in which she confessed everything. Reading the letter Arbenin lost his mind. The character of Arbenin brings to mind Nietzsche's phrase: "Because every drive craves mastery" (Nietzsche, 2002, p. 9). Namely, this rich, noble and powerful character also inholds some impulses like winning ambitions and killing. Thus it is impossible not to share Nietzsche's this assumption.

In Play we could understand better Arbenin's behaviors because of his anger, with Nietzsche's following words: "Because the angry man, and anyone who is constantly tearing and shredding himself with his own teeth (or, in place of himself, the world, it is God, or society), may very well stand higher than the laughing and self-satisfied satyr, considered morally. Considered but in any other way, he is the more ordinary, more indifferent, less instructive case. And nobody lies as much as the angry man" (Nietzsche, 2002, p. 28).

Start of Play with a gambling table scene, going of noble people constantly to gaudy invitations nad ball, fidelity and murder are issues that Lermontov criticised. As Andreeva states, In "Masquerade", it's possible to see the conflicts and problems that the writers in the second half of the 19th century also touched on them later. During this period, in Russian literature the problem of character has been one of the most important themes. For mentioned period's Russian writers, choice, freedom, the loss of moral norms were description of contemporary heroes. So, there should be known Lermontov and his heroes (АНДРЕЕВА, 2014, p. 211).

In his work Lermontov described his hero individual and both within the family, and in the community; he also showed the individual-society relationship. There were expressed falsehood of individuals and society (more noble class) and conflicts between them.

Another reason of our handling Lermontov's this work in the light of social criticism theory is especially in this work Russian society (more upper class) of the 19th century is given. The author has given the noble from the point ofcritical view. According to him, in mentioned period most of the noble were people devoid of good sense and with a twofaced behaviors. That's why the author used the metaphor of masquerade which is also gave its name to Play. Masquerade is actually a symbol. The author has actually wanted to give this message to readers: being there, noble people belonging to the high class, are those that hid behind the masks. Andreeva has been described masquerade as a game. In this game, all ranks and classes of people have been absent. This game is a leisure class's entertainment element. (АНДРЕЕВА, 2014, p. 212). However, the masks don't have any soul. In this work, these situations can be clearly seen:

Под маской все чины равны,

У маски ни души, ни званья нет, - есть тело.

И если маскою черты утаены,

То маску с чувств снимают смело. (АНДРЕЕВА, 2014, р. 212 )

(Behind the masks all ranks are equal,

The mask have no soul, no title, — - has a body. 
And if lineaments were hidden by the mask,

Then it can be removed the mask bravely from the feelings. (Translated by Hacizade, L. [9])

So it would be wrong to expect humanitarian values from soulless masks. Even the use of such a metaphor, shows that the author thinks of good and evil, just like Nietzsche, individually, too. Author also wanted to show that, moral values may be formed by community and circumstances. Likewise, "Nietzsche always stressed the role of emotions and irrational forces in forming human values." (Warburton, 2016, p. 259).

The mask is a hiding cover. It covers not only the faces and characters, but also immoralities of people:

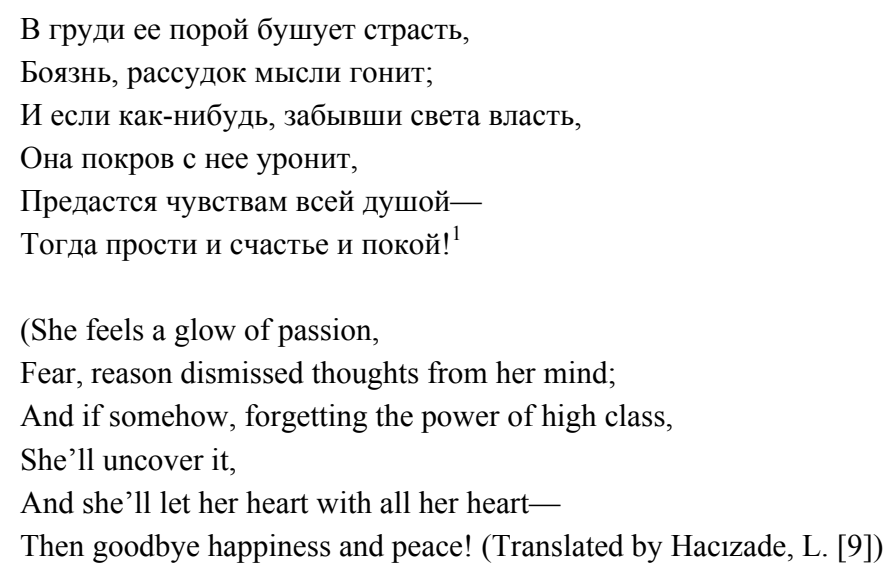

Nietzsche also touched on the masks. According to him, every profound spirit needs a mask:

Everything profound loves masks; the most profound things go so far as to hate images and likenesses. ... Malicious cunning is not the only thing behind a mask - there is so much goodness in cunning. ... Every profound spirit needs a mask: what's more, a mask is constantly growing around every profound spirit, thanks to the consistently false (which is to say shallow ) interpretation of every word, every step, every sign of life he displays. (Nietzsche, 2002, pp. 38-39).

The most indicated and criticised by Lermontov situation throught the work is the community actually is lacking in any moral values:

\footnotetext{
И если бы ты мог на карту бросить душу,

То я против твоей-поставил бы свою.

$\ldots$

Ты! бесхарактерный, безнравственный, безбожный,

Самолюбивый, злой, но слабый человек;

В тебе одном весь отразился век,

Век нынешний, блестящий, но ничтожный.

Наполнить хочешь жизнь, а бегаешь страстей.

Все хочешь ты иметь, а жертвовать не знаешь;

Людей без гордости и сердца презираешь.

.

Ваш муж злодей, бездушный и безбожный. ${ }^{2}$

(And if you could stake all your soul on one gamble,

Then I could stake all mine-against yours.
}

\footnotetext{
1 Лермонтов, Михаил Юрьевич. Маскарад. (“Masquerade”) http://lib.ru/LITRA/LERMONTOW/maskarad.txt

2 Лермонтов, Михаил Юрьевич. Маскарад. ("Masquerade") http://lib.ru/LITRA/LERMONTOW/maskarad.txt
} 
..

You! worthless, immoral, godless,

Selfish, malevolent, but a weak person;

A whole century reflected on you,

The present, brilliant but miserable century.

You want to fill your life, but avoid the passions.

You want to have all, but don't know to sacrifice;

You despise the servile and heartless people.

$\ldots$

Your husband is a villain, emotionless and godless. (Translated by Hacizade, L. [9])

As a matter of fact, Nieztszche's words "people who represent more nobly bred types are less likely to turn out well" (Nietzsche, 2002, p. 56), better reveals the good and bad understanding of the noble class.

To show better the situation of noble's lack of human values, author, has put Arbenin in opposite of Nina. Thus these two contrasting characters, creating a ground colour to each other, showed better their contrasts. Just like black and white. Yevgeniy Arbenin is a selfish, self-loving man and despises all kinds of sincere feelings; on the other hand, Nina Arbenina is loves her husband, she is a faithful and naive young woman. Nietzsche explains his work by comparing good with bad; Lermontov also compared these two characters. It's not for nothing that at the end of the Play of Nina died. Killing his characters in the work writers, actually want to give the message: they want to explain either the opinion defended in the book isnt'valid for that period / society, or heroes are unacceptable for that period / society. We can also see the same message in this work. Lermontov, indicated that so pure and clean character like Nina couldn't live in too degenerated and lack society.

The relationships between male and female in noble class also took place in the work. But among the nobility the games won or lost in gambling are preferred to feelings like love and faith. For example, not the person who cheated his / her wife / husband, but the one, who gambled away is considered lost their honor:

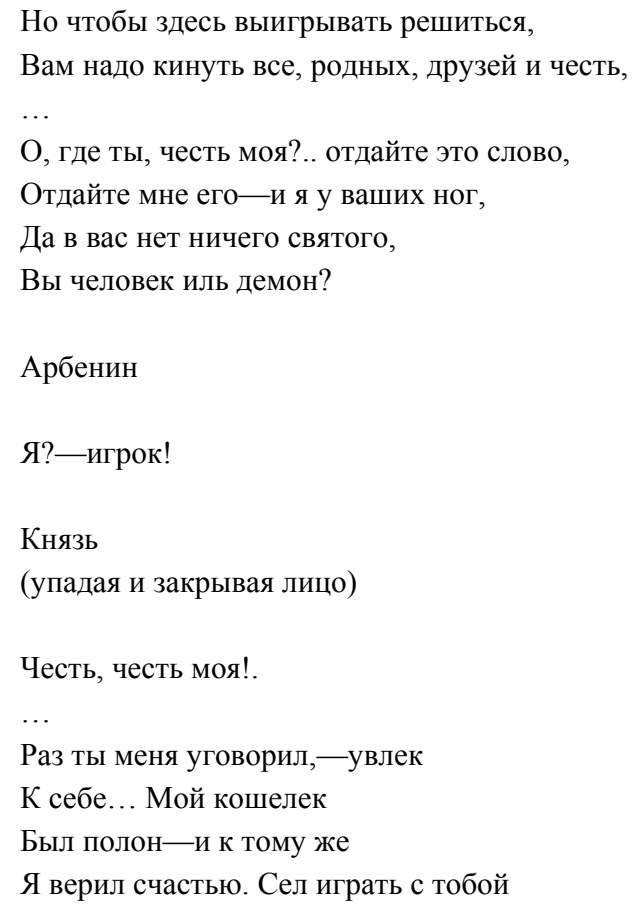


И проиграл, —отец мой был скупой

И строгий человек. И чтоб не подвергаться

Упрекам-я решился отыграться.

Но ты, хоть молод, ты меня держал

В когтях,-и я все снова проиграл.

Я предался отчаянью-тут были,

Ты помнишь, может быть,

И слезы и мольбы... В тебе же возбудили

Они лишь смех. O! лучше бы пронзить

Меня кинжалом. Но в то время

Ты не смотрел еще пророчески вперед.

Арбенин хочет вскочить, но задумывается.

И я покинул все с того мгновенья,

Bce: женщин и любовь, блаженство юных лет,

Мечтанья нежные и сладкие волненья. ${ }^{3}$

(But for deciding to win here,

You should leave all, the relatives, friends, and the honor,

Oh, where are you, my honor ?.. give that word to me,

Give it to me-and I'll implore mercy,

In you there is nothing sacred,

Are you a man or demon?

Arbenin

Me? - the card player!

Prince

(falling faint and covering his face)

Honor, my honor !

Once you persuaded me - called my attention

To yourself ... My wallet

was full — and, moreover,

I believed in happiness. I sat down to play with you

And lost the game,- - my father was a stingy

and unpermissive man. And for not to be affronted-

I decided to gain the return game.

But you, though young, you pulled

My strings - and I lost again.

I got desperate - there were,

You remember, maybe,

Tears and prayers ... Awoke in you

Just laugh. Oh! Better to stab

At me. But at that time

You have not foreseen future yet prophetically.

\footnotetext{
3 Лермонтов, Михаил Юрьевич. Маскарад. (“Masquerade”) http://lib.ru/LITRA/LERMONTOW/maskarad.txt
} 
Arbenin wants to start to his feet, but thinks better of.

And I left everything since then,

All: women and love, the hapiness of young ages,

Gentle dreams and sweet excitements. (Translator. Hacizade, L. [9])

It's also seen in the work good-bad contrast by comparing man-devil:

Вы человек иль демон?

$\cdots$

Улыбка злобная, глаза... стеклярус точно,

Взглянуть-не человек,- а с чертом не похож. ${ }^{4}$

(Are you a man or demon?

...

Smile is angry, eyes ... exactly glass bead,

Not man—but does not look like devil. (Translator. Hacizade, L. [9])

In fact, Lermontov, in that way brings the question to mind: phenomenons accepted good / bad are for whom good or bad? We see the same approach in Nietzsche's work, too: "We do not consider the falsity of a judgment as itself an objection to a judgment; ... To acknowledge untruth as a condition of life: this clearly means resisting the usual value feelings in a dangerous manner; and a philosophy that risks such a thing would by that gesture alone place itself beyond good and evil" (Nietzsche, 2002, p. 7). The same situation can be seen in the character of Arbenin. Hero's behaviors that normally considered too bad and unacceptable, gained different dimensions from the point of Nietzsche's view: "Whatever is done out of love takes place beyond good and evil. ... We have to repay good and bad: but why do we have to repay precisely those people who did us the good or bad?" (Nietzsche, 2002, pp. 70-71). In this case these behaviors should not be considered as good or bad, leaving aside all kinds of social and moral norms

In this drama, Lermontov opposed to social injustice by showing us hypocricy of the noble and church and injustice of courts. The name and theme of work are parallel: the noble that wear masque, are hiding their real faces. Hero- Arbenin despises the high society around him but at the same time he couldn't avoid its defects. He listened to gossips about his wife and killed her. In Arbenin we can see many things like lie, protestor of defects and also the man that couldn't overcome his egoism. In this drama while author was showing us high society it can be seen satiric language. According to Nietzsche, to handle the subject of good and evil especially in the moral dimensions can vary to the period and society; but generally, the things that can bring harm to the community were seen as immoral.

As we said before, Lermontov was also a great fan of Shakespeare and Shakespeare had influence on him for interesting in psychology in literature. And in the drama that is a material of our research has many similar points with Shakespeare's "Othello". Our study has also a point of view like analyzing the place of a Russian writer in the parallel of Europian literature. Themes of both dramas are very close to each other. In both heroes are very honorable and proud. Both are bored with society around them. And both got married the heroines that they fell in love. But because of the gossips both killed their loved wives. There are some differences between dramas like the symbols of "cheating", etc.

4 Лермонтов, Михаил Юрьевич. Маскарад. (“Masquerade”) http://lib.ru/LITRA/LERMONTOW/maskarad.txt 
In different periods, in different cultures the interaction between authors is quite natural; at some point almost everything related to human was includedin literature. As Moran pointed out, "the benefit of art to society is to make people understand each other better" (Moran, 2004, p. 130). It's not a surprising situation that, Romanticism, that is one of literary movements which brought the human, classification of people and communities into the forefront, existed in 19th century. In almost all history of the world mankind had a highly complex process in this period. Thus, writers and intelligentsia have led to society in a didactic manner and they have strived for an ideal society. Suggestion of idea of the moral ideas and overman ideology in this period is natural. As Aytaç said, "Although contemporary various literary movements and literary science methods ignored this tendency, according to traditionalist-conservative authors, critics and readers the morality, aesthetics are still the determinant for evaluation" (Aytaç, 2009, p. 215). Of course, Aytaç's these words are hardly applicable to Nietzsche. German philosopher, while the good-bad evaluating, considered them in individual dimension, rather than social dimension, like most critics. Undoubtedly, in the period that lived Nietzsche, moving of mankind from socialism toward individuality has also affected above mentioned situation.

\section{Literature}

We need to apply not only literary, but also the philosophical and theoretical sources; because, handled subject requires theoretical and comparative (different cultures, literatures, different periods of literature) evaluations.

\section{Methodology}

Our study is analyzed by the method of researching, analysing, theory and comparing.

Firstly, author (Lermontov) has been introduced in its period. The resources that contain information about the author are checked on. It's also touched on briefly his contemporary other Russian critics and authors, by shortly introducing this Russian, and also tried to present Russian society in mentioned period. For this information there are used resources of history of literary. Then it's explained the historical formation and development of the social criticism theory. For this information, books on literary theory, philosophy and theory were examined. The famous German philosopher Nietzsche's work has been viewed, with revealed theoretical knowledge, Lermontov's "Masquerade" is analyzed in detail in the light of deterministic relationship.

For all of these studies qualitative and quantitative analyse methods are used nested together. Besides, it's also at times referred a comparison method. Such comparisons are made not only between works or authors, but also between periods, cultures and even fields.

\section{Conclusion}

Thanks to Nietzsche's theory and his work, if we approach to those times' moral values and judgments of Russian social, then we can see that Lermontov asks this question: which one of these values is bad and which is good? And good for whom, bad for whom? Author is against society order of those times' Russian society. Religion and moral understandings of "Religious" society are seen better through the theory of Nietzsche. Lermontov determined that each society, each person has own moral values, his own thoughts on concepts of good and bad. Besides, Lermontov throughout his life had asked these questions, these contrasts. Both Nietzsche 
and Lermontov have these kind of questions born from contrasts.

As a result we can say that Nietzsche and Lermontov both had conflicts between contrast concepts in their mind and these conflicts were same.

\section{References}

Aktulum, K. (2013). Folklor ve Metinlerarasılık. Konya: Çizgi Kitabevi.

Aktulum, K. (2000). Metinlerarası İlişkiler (Intertextuality). Ankara: Öteki Yayınevi.

Aytaç, G. (2009). Genel Edebiyat Bilimi. 2. Baskl (General Literary). İstanbul: Say Yayınları.

АНДРЕЕВА, В. Г. (2014). ««Маскарад» М.Ю. Лермонтова и русский роман второй половины ХІХ века» (“Masquerade” of Lermontov and Russian Novel In The Second Half Of 19th Century). Известия вузов. Серия «Гуманитарные науки» 5(3), 211-216.

История русской литературы ХІХ века (первая половина) (1973). (History of Russian Literary In 19th Century ) Под ред. С. М. Петрова. Москва: «Просвещение»

КАЧУРИН, М. Г., \& МОТОЛЬСКАЯ, Д. К. (1990). Русская литература (Russian Literary). Под ред. Н. Н. Скатова. Москва: «Просвещение».

КУДАЧКИН, Д. А. (2015). «ПРОБЛЕМА ДОБРА И ЗЛА В ФИЛОСОФИИ ФРИДРИХА НИЦШЕ» (A Problem Of Good and Evil In Friedrich Nietzsche's Philosophy). Приволжский научный вестник, 6-3(46), 98-101, Ижевск.

ЛЕБЕДЕВ, Ю. В. (2002). Русская литература ХІХ века (Russian Literary In 19th Century). Москва: «Просвещение».

ЛЕРМОНТОВ, Михаил Юрьевич (“Masquerade”). http://lib.ru/LITRA/LERMONTOW/maskarad.txt

Moran, B. (2004). Edebiyat Kuramları ve Eleştiri (Literary Theories and Criticism). İstanbul: İletişim Yayınları.

Nietzche, F. (2001). İyinin ve Kötünün Ötesinde (Beyond Good and Evil). Çev. Ahmet İnam. İstanbul: Yorum Yayınevi.

Nietzsche, F. (2002). Beyond Good and Evil (J. Norman, Trans.). R. -P. Horstmann (Ed.). New York: Cambridge University Press. РЕЗНИК, Ю. М. (2007). «СОЦИАЛЬНАЯ ТЕОРИЯ И ТЕОРЕТИЧЕСКАЯ СОЦИОЛОГИЯ НА ПУТИ ИНТЕГРАЦИИ» (Social Theory and Theoretical Sociology On The Way of Integration). Социологические исследования, Москва, 9, 17-24

СОКОЛОВ. А. Г., \& МИХАЙЛОВА, М. В. (1982). Русская литературная критика Конща ХІХ начала ХХ века (Russian Literary Criticism. The End Of 19th-The Beginning Of 20th Century). Хрестоматия . Москва: «Высшая школа».

Warburton, N. (2016). Felsefenin Kısa Tarihi. Çev. Güçlü Ateşoğlu. 12 (The Short History of Philosophy). Baskı. İstanbul: Alfa Basım Yayım. 